\title{
Protestant Churches and Dissidents Under Dictators: Comparing the Gikong Presbyterian Church With German Churches in the GDR
}

\author{
Samuel Shengfei Hung \\ National Taiwan University, Taipei City, Taiwan \\ National University of Kaohsiung, Kaohsiung, Taiwan
}

\begin{abstract}
The literature generally refers to Chiang Kai-shek and his son Chiang Ching-kuo as "authoritarian" leaders. This paper will argue that, in fact, they governed more like totalitarian dictators. Their tight control over every sector of Taiwanese society was not inferior to the dictatorial rule of the German Democratic Republic (GDR). Despite the tight control exercised by the GDR regime and the Chiangs, however, Protestant churches still managed to become shelters for dissidents in both East Germany and Taiwan. Also, in both localities, church buildings became gathering locations and church newsletters optimal channels for communications. Moreover, the dissidents that had kept hidden in East German churches eventually led the protests that overthrew the GDR's communist regime. Similarly, in Taiwan dissidents from the Gikong Presbyterian Church became the oppositional leaders that facilitated the first democratic party rotation in Taiwan. This article explores why the above became possible by examining the following hypothesis: The oppressive policies of dictatorial regimes transform churches into breeding grounds for dissidents because of the alternative ideologies and values they provide. Moreover, the paper will show how civic movements can develop in churches even under authoritarian regimes.
\end{abstract}

Keywords: Chiang regime, East Germany, dictatorship, church

\section{Introduction}

Both Taiwan under the rule of Chiang Kai-shek and his son Chiang Ching-kuo and East Germany under the rule by the Socialist Unity Party of Germany (SED) were dictatorships. Although the former is generally referred to as "authoritarian" and the latter as "totalitarian", essentially the differences between the two can be disregarded. According to Friedrich and Brezinski (1965), totalitarianism has five characteristics: 1) The government sets the ideology with the goal of thoroughly transforming society; 2) The masses only have one political party, whereas all other parties exist only nominally; 3) Political police exercises rule by terror; 4) The content of mass communications and cultural activities are strictly controlled and are used to create a cult of personality; and 5) The state tightly controls economic activities. In the light of these five characteristics, when comparing the regimes of the Chiang's with SED rule neither of the two is inferior in any respect.

In fact, when it comes to personality cults, the halo that surrounded the two strong men of East Germany,

Samuel Shengfei Hung, Ph.D. candidate, Department of Political Science, National Taiwan University; Lecturer, General Education Center, National University of Kaohsiung. 
Walter Ulbricht, and Erich Honecker, was insignificant compared to legendary status the two Chiang's possessed in Taiwan. After Ulbricht ignored Leonid Brezhnev, the leader of the Soviet Union at the time, he was forced to resign (Kuppe, 1999) ${ }^{1}$. And after Gorbachev clearly did not support Honecker, soon after the people forced him to step down from office (Leonhard, 1990) ${ }^{2}$. By contrast, in Taiwan even though 30 years have passed since the lifting of martial law, the bronze statues of Chiang Kai-shek remain hard to offend ${ }^{3}$. In fact, there are even people in contemporary Taiwan who revere Chiang Kai-shek like a god ${ }^{4}$. This is even more true for Chiang Ching-kuo, who still stably maintains his position as the most admired leader in political circles 5 .

Political science distinguishes totalitarianism and authoritarianism as follows.

The purpose of dictators (in totalitarian regimes) is not only to maintain power, but also to thoroughly transform society. In order to achieve these goals, they will not just exercise control over the thought, speech, and actions of the people, but they will also seek to direct and transform these, through both political and socialization means. (Lu, 2014, pp. 144-145)

Contrarily, authoritarianism only requests people to become "docile subjects" in political life. This differentiation demonstrates that the rule of the two Chiang's over Taiwan was closer to totalitarian rule than to authoritarian rule. In fact, both "totalitarian" and "authoritarian" regimes are actually dictatorships (Lu, 2014). As such, the difference between the two systems is only one of degree, not of essence. However, if we really want to differentiate the two in even more detail we should classify the rule of the two Chiang's in Taiwan under "totalitarianism". Currently, however, Taiwanese academic circles tend to classify it under “authoritarianism". In doing so, scholars not only deceive others, but also themselves.

\footnotetext{
${ }^{1}$ Because Ulbricht in 1970 persisted that the GDR had already become a Socialist German Nation State, he demanded from West Germany, which at the time wanted to negotiate, to quit talking about a unified German Nation, causing the negotiations to be shelved. West Germany, then, through a detour, first normalized relations with the Soviet Union, and then through the Soviet Union pressurized East Germany to negotiate with West Germany. When Soviet leaders contacted Ulbricht, he then used a kind of senior revolutionary attitude to lecture them. Consequently, in 1971 Ulbricht was forced to step down due to his old age and replaced by Honecker as the first secretary.

2 On 7 October, 1989 the GDR celebrated its 40th anniversary. Gorbachev, who had been invited as honored guest, during his speech then criticized the SED for its unwillingness to implement reforms by stating:"Those who are unable to keep up with the times will be punished by the reality of life". This statement convinced the East Germans that Honecker had already lost the support of the Soviet Union and that the Soviet Red Army would not come to assist with the suppression of the East German masses. Consequently, on the 9th of October 70,000 people took to the streets in protest in the GDR's most important industrial city Leipzig. Cities all over the GDR followed: in Halle 20,000 people demonstrated, in Plaue 15,000. On 16 October, the protests intensified everywhere, causing 120,000 to 150,000 people to take to the streets in Leipzig (that is, one out of five of the entire population). Soon after, every Monday people would demonstrate in Leipzig, going into history as the "German Revolution" or the "People's Spring". Forced by the circumstances, Honecker resigned from his leadership positions in the party and army and declared his official stepping down from office.

${ }^{3}$ On 28 May, 2014, already 27 years after the lifting of martial law restrictions, there was still a military education instructor in $\mathrm{Fu}$ Jen Catholic University who threatened to call the police into the campus to investigate who put the sticker on a bronze statue of Chiang Kai-shek stating: "Indefinitely support the legacy of Chiang Kai-shek to be removed from the campus". This instructor even bellowed with rage: "Mr. Chiang in my view is a great person", "I have been a captain in the military police! I have been a prison warden! How could I not know what kind of crime you have committed?" "Why did you stick this sticker! Stupid child!" see Apple Daily, 29 May 2014, 20:42 latest news.

${ }^{4}$ After Chiang Kai-shek passed away, some people cast their idol in iron and started worshipping him. Some even built temples for him and offered their sacrifices there. For instance, in Chichin district in Kaohsiung City there is a Mr. Chiang Temple (蔣公 廟) and in Hsinchu in the Magnificent Heaven Temple (天宏宮) the main god worshipped is also Chiang Kai-shek. The Kuixing Temple in Danshui also worships the "respective fair and honest Mr. Chiang” (蔣公中正天尊).

5 On 23 April, 2013 the Epoch Times reported: "Over the last 15 years, the result of every poll that asked "who has made the greatest contribution to Taiwan?", Chiang Ching-kuo always came out as number one. Retrieved from http://www.epochtimes.com/b5/13/4/23/n3853166.htm
} 
Both the two Chiang's in Taiwan and the SED in East Germany tightly controlled society into even its smallest corners. Both regimes severely suppressed dissidents. Although this was the case, the regimes were still unable to dominate the thought of all people. In both countries, still groups of people existed that were not brainwashed by the official ideology and dared to voice different ideas.

In Taiwan, after the Lin residence murder case（林宅血案） occurred in 1980, a group of family members of political victims formed a household religious service in order to console each other. This later became the Gikong Presbyterian Church. The church not only bought the Lin residence in which the murder case had taken place, but also pointed out the names of prisoners of conscience in the weekly church paper and prayed for them. Moreover, the church also conducted religious services to express its gratefulness for those being released from prison. Since its establishment, the Gikong Presbyterian Church has not only provided dissidents with spiritual sustenance and moral pillars, but it has also displayed its capabilities to organize and connect, which in the light of the relationship between politics and the church in Taiwan, deserves to be especially valued.

The emergence and practices of the Gikong Presbyterian Church, however, are not unique. Most of the members of the citizen groups that caused the East German communist regime to collapse in 1989 had also participated in church activities in their early days. Many of the leaders of this group were even the children of pastors, or were even pastors themselves. Church buildings provided them with gathering places, and the weekly church papers became vital channels of communication. The church also gave them an alternative way of thinking independent from the official ideology provided by the state.

The rest of this article will analyze why under the strict monitoring dictatorial regimes some protestant churches came to play the role of protector of dissidents and even actively used church documents as channels of communication. The paper will inspect and verify the following two hypotheses: 1) Under the oppressive policies of dictatorships, protestant churches will naturally turn into a breeding ground for dissidents and will train them to promote citizen movements; and 2) Protestant churches facilitated the development of citizen movements due to the alternative ideology and system of values they provided, setting them apart from the one provided by the dictatorial regimes.

\section{Societal Controls During the Two Chiangs and the SED}

The Kuomintang (KMT) of the two Chiangs and the SED of East Germany were both Leninist-style parties that strictly controlled each segment of society.

\section{Control of Taiwanese Society During the two Chiangs}

After Chiang Kai-shek was defeated by the Chinese Communist Party (CCP) on mainland China and had fled to Taiwan, he appointed his son Chiang Ching-kuo and others to form the Central Reform Committee (CRF). The goal of the CRF was to reorganize the KMT organization along a Leninist-style political party model (Xu, 1996, p. 199). Consequently, the CRF assigned KMT members with the task to first infiltrate into all popular associations and then to develop their organizational systems and acquire leading positions in them. "The leading cadres of the party masses should be in every social class and in every profession. Through elections they should also participate in the legislative assembly and work with the government. In terms of quantity they should hold the majority of the seats required by the ruling party, and in terms of quality they should know well the ideology and policies of the party and make sure that these are implemented 
accordingly" ${ }^{\prime 6}$. Their work was not limited to the strengthening of regime institutions. In addition, they should also dominate and strengthen all non-governmental organizations in society. For instance, "when organizing labor unions, they should first establish its core party organization, with the goal letting workers themselves conduct its actual organization" (ibid, p. 11). Also, "before starting the organization of farmer's cooperatives and fishermen's associations they should first set up the party organization" (Central Reform Committee of the KMT, 1978, p. 21). Moreover, they should "strengthen the leadership of young female intellectuals-to make sure that everybody does what one excels at, each according to his or her ability - take part in social enterprises and from there organize activities, all in order assist the government to complete combat preparations"

In short, through the internal development of an organized party system and the obtaining of leadership roles within civil society groups, such as labor unions, farmer's cooperatives, fishermen's associations, irrigation associations and youth, women's, and cultural circles, the Chinese KMT successfully controlled each segment of Taiwanese society.

In addition to the above, the regimes of the two Chiangs also used secret police to tightly monitor Taiwanese society. In 1955, Chiang Kai-shek broke up the Central Bureau of Investigation and Statistics (CBIS, Zhongtong) and the National Bureau of Investigation and Statistics (Military Commission) (NBIS, Juntong), which had formerly been responsible for intelligence gathering, and reorganized them into the Ministry of Justice Investigation Bureau (MJIB) and the Military Intelligence Bureau (MIB). The MJIB and MIB were to take charge of the safeguarding, through thought examination, of government civil service institutions and society in general. Therefore, they set up offices in institutions at all levels of the establishment. Whereas these offices were originally called "safety offices" (安全室), their names were later changed to "second personnel offices” (人二室) (Li, 1988, pp. 39-46, 77). Through such a design, the secret police were able to control the entire government bureaucracy.

For people not affiliated to any institutions or schools, however, it was also nearly impossible to escape monitoring by the secret services. The Taiwan Garrison Command, established by Chiang Kai-shek in 1958, was responsible for the imposition of martial law, the safeguarding of society in general, the administration of cross-border traffic, cultural inspections, and the examination of mail, martial law trials, etc. As such, during the regimes of the two Chiangs, the Garrison Command was the principal work unit taking care of thought control. The unit used various reasons-including the usage of vulgar language, playful scolding, even secret grudges or grief, in fact, anything abnormal was not allowed (Shen, 2013) - to ban certain books, magazines, plays, and songs. For instance, the at the time very popular singer known as the "Queen of hats" (Feng Fei-fei) was once falsely accused by a Garrison Command official for making obscene jokes. Because of this she was

\footnotetext{
${ }^{6}$ Excerpt from: "Essential Points for the Leadership of the Party Masses" (黨的群眾領導綱要), recorded in the document stored at the Research Institute for Revolutionary Practices (革命實踐研究院) titled: “Party, Government, and Military cadres joint combat research team second term, conclusions of each discussion topic on party affairs” (黨政軍幹部聯合作戰研究班第二期 黨務組各項專題討論結論). Taipei: Research Institute for Revolutionary Practices (1954, p. 72)

${ }^{7}$ From page 74 of the "Mobilization Tasks of the Party", recorded in the Research Institute for Revolutionary Practices' "program and reference materials of the Institute's 1-11 term closing discussion forum for researchers on "Four Kinds of Reformative Movements" Taipei: Research Institute for Revolutionary Practices

8 "Based on research of 989 songs prohibited by the Taiwan Garrison Command, ten main reasons can be pointed out for banning songs: 1) ideologically leftist, Chinese communist propaganda; 2) plagiarizing Chinese communist scores; 3) depressing lyrics, influences the morale of the people; 4) content absurd or weird, harms mental and physical health; 5) encouraging licentiousness, impairs good and honest social customs; 6) violent lyrics, jeopardizes the education of society; 7) encourages hatred and conflict, will influence law and order; 8) reports errors of the times, will let people misunderstand the situation; 9) vulgar language, playful scolding; 10) secret grudges or grief, anything abnormal."
} 
disciplined through prohibiting her to sing (Guan, 2012). The Garrison Command even banned a canvas by the painter Li Mei-shu that portrayed peasant women washing clothing at the riverside because the people in the painting were wearing conical bamboo hats, which was perceived as propagating independence (Li Mei-shu Memorial Gallery, 2004). The harm Garrison Command did to Taiwanese society was so deep that even up until today many people, when doing something that might displease the authorities, will still feel restricted by a kind of "internalized Garrison Command" (Wei, 2013, p. 298).

When it comes to the church, although the two Chiangs also claimed themselves to be Christian (Chiang Kai-sheks testament claims that there was "no time in which he did not consider himself a true believer in Jesus Christ"), they still exercised harsh control over society. Local servants that helped foreign missionaries to take care of household duties would even be called in by the authorities for detailed questioning (Thomberry, 2011, pp. 84-86). Foreign missionaries were also shadowed (ibid, pp. 106-107) ${ }^{9}$. News also exists of intelligence personnel that would come to churches to monitor the proceedings (The Presbyterian Church in Taiwan, 1999, pp. 48, 51, 110).

\section{Societal Controls During the SED Regime in East Germany}

The Socialist Unity Party of Germany (SED) emerged when the Communist Party of Germany (KPD) merged with the Social Democratic Party (SPD) under the power and influence of the Soviet Union after it occupied East Germany. In essence, the SED was still a communist party. Hence, the SED governed society with the party as the core. Besides this, the SED left intact a few political parties, unions, women's associations, youth organizations, and cultural associations without actual power and incorporated them into the so-called Democratic Bloc (DB) to assist the SED with governance. Even further from the center of power was the National Front (NF), which was responsible for the integration of all the 19,400 large and small organizational groups within the borders, e.g., gardening societies, bee herding associations, and even committees responsible for the management of residential areas (Witt, 1996. pp. 78-92) ${ }^{10}$. The nature of the NF's work was thus so detailed that even neighborhood communities belonged to the scope of their services. The goal of their activities was to make sure that even the people that were not affiliated with any political party or mass organization could still be mobilized by the feelers of the National Front.

The high-pressure control methods of the SED were thus on par with those of the two Chiangs.

The SED also had its own secret services, named the Stasi (The Ministry for State Security), which originated from the Soviet intelligence organization the KGB. After the Stasi's third chief Erich Mielke came to power in 1957, it progressively extended its tight controls over society, and the organization rapidly expanded. When Mielke just took up his position the Stasi only had 14,000 full time staff members, 20 years later this number had increased to 33,000 , and another twenty years later this amount had double again to 66,000 . On the eve of unification in 1987, the number had even increased to 99,000 (Henke, 1995, p. 723). Next to this, the amount of unofficial workers (inoffizielle mitarbeiter) listed even exceeded $300,000^{11}$. When keeping in mind

\footnotetext{
9 This was probably not a stand-alone case. The current author also remembers German missionaries that had nothing to do with politics telling him when he was young that they were followed everywhere they went on the Taiwanese countryside.

${ }^{10}$ In comparison to people who were not affiliated with any associations, the GDR regime would harass less those people who belonged to these four parties, and would even give these people more opportunities for promotion. Bundeszentrale für politische Bildung, Information zur politische Bildung 205: Die DDR. (Bonn: Bundeszentrale für politische Bildung, 1988), pp. 12-13.

${ }^{11}$ For more details, please search "Stasi” at Wikipedia, the free encyclopedia. http://en.wikipedia.org/wiki/Stasi. Besides, 關根伸

一郎 (1995) conversely reports that there were in between 3 and 5 million secret police people listed, see《ドイッの秘密情報機

關》 Tokyo: Kodansha, pp. 189-190.
} 
that East Germany at the time had only a population of 16.6 million, such an enormous network of secret agents can be considered to have been able to monitor almost everyone in society ${ }^{12}$. Moreover, many professionals dealing with personal privacy, such as lawyers, doctors, teachers, sports trainers, and naturally also encompassing the clergy, were all requested to cooperate with the Stasi (Merkl, 1993, p. 101).

The mission of the Stasi, next to dealing with the international ${ }^{13}$, especially its intelligence work in West Germany (Wu, 1995) ${ }^{14}$, also included the monitoring of every segment of East Germany itself. When during the 1970s interactions between East and West Germany rapidly increased and grassroots movements started to spring up hidden in East German churches, the Stasi tightened even further its comprehensive monitoring in the GDR. As a result, the "non-aligned secret agents" network was established at this time.

Although the high-level cadres of the SED were formally all atheists, actually more than half of its party members were Christians (Goerner \& Kubina, 1995, p. 630). This had something to do with the fact that churches had also resisted the Nazi Party, making the Communist Party, which was also against Hitler, originally rather lenient towards the Christian church (Zhu, 2010, p. 70). However, at the end of 1947, the authorities unveiled a strategy that limited the church's influence to the spiritual world, and excluded it from public works and the political domain (Thumfart, 2002, p. 381). The church did not respond positively to this, causing the SED to adopt a tightening policy on the church from the beginning of 1948. This policy especially focused on limiting youth work of the church. After the establishment of East Germany, the church also became reorganized into the National Front.

After West Germany refused Stalin's conditions in July 1952, Stalin inspired the SED to expedite the Construction of Socialism program. To the church this meant further oppression: funds were cut in half, preaching work in public locations was banned, youth works were suppressed even more strongly, and church deacons were arrested (Maser, 1999, p. 488). After Stalin passed away, however, the Soviet authorities were of the opinion that if they continued to adopt high-pressure methods towards the East German church, this would only destabilize East German society. Hence, on 14 March 1954, the SED Central Committee and Politburo changed their position. From then on, as long as the Protestant and Catholic churches would publicly support socialism, they would be fine (Thumfart, 2002, pp. 381-383).

Despite this policy change, East Germany still continued to treat devout Christians as "second class citizens", Consequently, believers encountered discrimination in education, on the job market, and when it came to promotions. Church activities also remained closely monitored (Zhu, 2010, p. 71).

\section{The Importance of the Gikong and GDR Churches to Dissidents}

Under the repression and surveillance of their respective dictatorial regimes, both the Taiwanese and the East German churches played important roles in the protection of dissidents.

\footnotetext{
12 On average, for each 50 East Germans there was one secret police agent monitoring. For more details, please see Klaus-Dietmar Henke, op. cit., p. 724.

${ }^{13}$ The scope of Stasi activities reached as far as South America. For instance, after the Pinochet Coup took place in Chile in 1973, and the new regime started suppressing and even eradicating leftists, Stasi members went there to rescue and escort back these leftists to East Germany. For more details, see the header Stasi at Wikipedia, the free encyclopedia. http://en.wikipedia.org/wiki/Stasi

14 West Germany's Chancellor Willi Brandt, who had initiated the Ostpolitik, had to step down from office in 1974 because his private secretary Günter Guillaume was discovered to be a GDR spy.
} 


\section{Gikong Presbyterian Church}

Within Christian circles in Taiwan, the first church that dared to voice criticism of the Chiang regime was the Presbyterian Church. They did so particularly during the 1970s, when Chiang Kai-shek handed over power to Chiang Ching-kuo. First, in December 1971, the Presbyterian Church put forward a "Declaration and Proposal with Regard to State Matters” (對國是的聲明與建議), in which it requested the government to thoroughly reform internal affairs by comprehensively reelecting all central public representatives. Second, in September 1975 the church also published a document titled “Our appeal” (我們的呼签), which urged the government to respect the constitution, and to care more about the general mood in society. Third, in August 1977 they again published a "Human Rights Manifesto", in which they advocated the right to self-determination of the people and advised the government to make Taiwan a new and independent country (Chen, 1991, pp. 92-97).

The emphasis on living a righteous life in this world and the pursuit of public welfare of the Presbyterian Church made its members invest a lot of time into reforming the country and participating in society ${ }^{15}$. This is underscored by the fact that important early democracy activists in post-war Taiwan, such as Thomas Liao (Du, 2004, pp. 26-28) and Peng Ming-min (Thomberry, 2011, p. 97), were all Presbyterian church members. Many political dissidents around the time of the Kaohsiung Incident were also related to the Presbyterian Church. If they or their family members were not members, they had been receiving consolation and encouragement from its members for a long time.

In fact, the establishment of the Gikong Presbyterian Church was directly related to the Kaohsiung Incident. On 10 December 1979, Tangwai members in Kaohsiung launched an "international human rights memorial day" activity. Under the manipulation of people with bad intentions, in the end this evolved into a bloody confrontation. The authorities blamed responsibility entirely on the initiators of the movement, and carried out a round of major arrests. Although he had neither actively participated in the movement nor spoken on stage during that day, three days later the provincial legislative Lin Yi-hsiung was arrested for groundless reasons and sent to prison (Luo, 2012, p. 33). Then, on 2 February 1980 (228), although his residence was under strict surveillance of the authorities, somebody still managed to sneak into his house with the intention of murdering his family members. Lin Yi-hsiung's mother, Lin Yu A-mei, and his mere 7 years old twin daughters Lin Ting-chun (林亭均) and Lin Liang-chun (林亮均) were killed. Only his eldest daughter, Lin Huan-chun (林奐均), survived after suffering serious injuries (United Daily, 1980).

The person who made it to the Lin residence first and discovered the tragedy was Lin Yi-hsiung's secretary at the time, Tian Chiu-jin $(\mathrm{Lu}, 2001)^{16}$. Her mother, Tian Meng-shu, immediately asked the

\footnotetext{
${ }^{15}$ Even more factions of the Christian church do not discuss politics, for various kinds of reasons. Many Premillennialists are of the opinion that since this world will ultimately perish anyway; Christians do not have to waste their efforts to transform it. They only thing they need to do is save as many people as possible before Judgment Day. Those who hold fast to the separation of church and state, contrarily, believe that the church should strictly maintain its independence and should not get involved in politics. Finally, under the scope of the Christian church, there are also religious leaders who take pleasure in building up ideological state apparatuses for leaders. Their specialty is to make rulers look more beautiful than they actually are. Although they appear not to talk politics either, in practice they often distort the Bible in order to rationalize the words and actions of the rulers and to demonize the opposition.

${ }^{16}$ On the day, this incident occurred eight figures that were sued by martial law because of their involvement in the Kaohsiung Incident were appearing publicly in court. The defending lawyer had thought of a way to allow the defendant's family members to be present. Lin Yi-hsiung's wife Fang Su-min was also informed to attend. Since she had not felt at ease leaving her kids at home, she had told her secretary Tian Chiu-jin to pay a visit to the residence after lunch. When Tian Chiu-jin at 14:00, she discovered Lin Huan-chun (林奐均) lying in a pool of blood, and urgently reported the case. Only after assistance come, did they discover that Lin Yi-hsiung's mother and the two youngest daughters had already passed away.
} 
Presbyterian church General Secretary Reverend Kao Chun-ming to start prayers with all the other pastors (Cheng, 1982, pp. 59-60). On 24 April, Reverend Kao Chun-ming was also arrested by the authorities for because he had assisted with hiding Shih Ming-te. Reverend Kao's wife Kao Li Li-chen (高李麗珍), after discussing with the pastors Weng Hsiu-gung, Shang Chen-chong, and Chen Er-yu, started a religious service to console family members of political prisoners (Xie, 2010, pp. 128-129) When Lin Yi-hsiung's wife Fang Su-min later encountered economic difficulties and wanted to sell the residence of delict and was unable to do so, the members of this religious service thereupon bought the house and established it as a gathering place under the name of Gikong Presbyterian Church (Xie, 2013, pp. 32-39).

The Gikong Presbyterian Church did not only provide religious services and consolation for the family members of direct political victims of the Kaohsiung Incident. After its establishment it was also considerate to others, and devoted its efforts to console political victims in general. One of the founding members and a defending lawyer of the Kaohsiung Incident, Lee Sheng-hsiung, pointed out in an article commemorating the 10th anniversary of the church that "because the Gikong Presbyterian Church prayed almost every Sunday for political victims in Taiwan, it became the church political victims and the people considerate about them liked to come to the most" (Lee, 1992, p. 47).

The first pastor the Gikong Presbyterian church appointed after its establishment three years earlier, Hsu Tien-hsien (許天賢), was himself also a political victim of the Kaohsiung Incident. Hsu was arrested by KMT secret agents during the 1979 Christmas ceremony (Hsu, 2012). Also because both members and clergyman of the Gikong church had either been implicated with political events, or had bravely stood up (against the authorities), very naturally "it became a spiritual consolation center for family members of victims and (former) political prisoners themselves. At the time, it was also the promotion center behind the joint praying assembly for family members of political victims held by Taiwan's Northern Region Presbyterian Church. Moreover, to provide essential (financial) assistance to political prisoners, prisoners of conscience, and family members of victims, the church also established the Love Fund (愛的基金) in order to assist all people in need of help” (ibid).

Next to visiting political prisoners in prison, the Gikong church also pointed out their names in the weekly church paper, and urged church members to remember them in their prayers (Xie, 2013, pp. 52-64). After these political prisoners would come out of prison, the Gikong church would then conduct religious services for them to express their gratitude (Xie, 2013, pp. 65-67). With regard to the family members of political victims, the Gikong church would not only provide spiritual support, for instance through praying gatherings, but also established the "Love Fund" (愛的基金) to provide (financial) assistance in critical situations, and the “Women's Exhibition Center” (婦女展業中心), which provided free courses for women teaching them how to survive on their own (Xie, 2013, pp. 70-82).

\section{Churches in East Germany}

The concern for public welfare displayed by the Gikong Church during the dictatorial rule of the two Chiangs in Taiwan could also be found on the other side of the globe in another dictatorship.

At the end of the 1970s, the New Social Movement that had engulfed West Germany now also started to influence East Germany. The movement asserted that the current system was unable to solve the present social problems and that therefore ways outside of this system needed to be considered, with the goal of providing society with an early warning system. The fact that the US and Soviet Union were both deploying 
medium-range missiles in Central Europe spontaneously triggered Peace Movements all over Western Europe. The people of East Germany also responded. Some commentators even (falsely) believe that this was the start of dissident groups in East Germany (Dielmeier, 2001, pp. 442-443). In fact, most members of these groups were affiliated with the church, where dissent had been brewing already for a longer period of time. Next to dissenting groups publishing publications themselves, church communications were also an important channel for their communications (Ye, 1999, p. 312). In 1981, the East German church entrusted a painter with the task of designing a shoulder emblem depicting a "sword changing into a plow", which was based upon prophecy 2:4 from the Book of Isaiah, "They will hammer their swords into plowshares and their spears into pruning hooks. Nation will no longer fight against nation, nor train for war anymore" ${ }^{, 17}$. The church then extensively distributed this emblem and it became the symbol of an independent East German Peace Movement. Many proponents of this Peace Movement started to use church locations and even borrowed the name of the church to register the movement, causing them to effectively carry out the peace movement in the name of religious activities (Zhu, 2010, p. 72).

At first, East European countries considered these peace movements anti-American. Therefore, they tacitly accepted and even encouraged the launching of similar activities. However, the peace movements were not only anti-American, they were also anti-Soviet. Upon that realization, the Eastern European countries changed their attitude and attempted to keep their activities under control (Zhu, 2010, p. 69). Thereupon the SED government requested the church to use its influence to soften the anti-voices that were increasing by the day. However, the higher levels of the church instead permitted even more grassroots movement groups to use the spaces of the church for their gatherings (Kellogg, 2001, p. 749). Although initially church audiences would conceal these persons during the gatherings, later many church-goers instead joined the grassroots movement groups (Pfaff, 2001, p. 286).

During the 1980s, the Protestant Church repeatedly made public demands with regard to issue, such as global peace, the safeguarding of human rights, and the protection of the ecology. These demands were all in line with those advocated by grassroots movement groups. Contrarily, the Catholic Church would voice concerns about the liberalization policies with regard to abortions and military training as a subject in schools and colleges. In the 1980s, activities that used appeals for peace, ecology protection and righteousness attracted the participation of more and more East German people. In February 1987, around 10,000 religious people cosigned a request to conduct opening up reforms in East Germany. In September 1987, the Olof Palme Peace March caused the entire world to realize that the GDR had already started changing. When Gorbachev incited reforms in the Soviet Union and the Eastern European Bloc, the Christian Church also stepped up and voiced its support for this (Maser, 1999, p. 495).

The Protestant Church also played an active role in 1989 in the movement that sought to overthrow the GDR regime. Not only did church representatives unite to publish public statements, advocate in favor of the freedom of association, reform of the electoral system, and the separation of party and state. Moreover, Protestants also actively conducted all kinds of lecturing activities in churches all over the GDR. Protestant church organizations launched protest marches, and gradually formed large-scale popular movements. Spontaneously and newly rising people's groups were also actively participated in by church people.

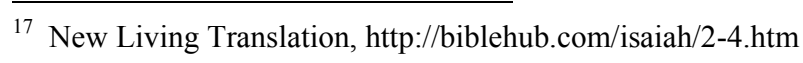




\section{The Reverse Effects of Oppression by Dictatorial Regimes}

The examples of the Gikong Presbyterian Church and the Protestant Church in the GDR have demonstrated the following two things. First, rather than effectively silencing the churches, the oppressive policies of the dictatorial regimes instead caused the churches to turn into breeding grounds for dissidents who then pushed for citizen movements. Second, the alternative ideologies and sets of values provided by the Protestant churches within Taiwan and the GDR caused citizen movements to develop within these churches.

When the secret police encountered dissenting voices during the regimes of the two Chiangs in Taiwan, their response was usually the hard suppression of these. This was frequently done through first naming dissidents 'communist spies' (匪諜), then arresting them and finally torturing them. After the 28 February 1980, Lin Residence Murder Case (林宅血案) the situation worsened, which is illustrated by the mysterious death on 3 July 1981 of Chen Wen-chen (陳文成事件), after he was interrogated by the secret police, and the 15 October 1984 murder of Henry Liu (江南命案) on United States soil. Few people could have imagined that such bloody suppression during the White Terror period would in fact awaken even more people and cause them to mourn the unrepentance of the authorities. Although it is true that the Presbyterian church's concern about dissidents and its constant criticizing of the government caused the authorities to use pro-government religious figures as a counter measure, nevertheless it managed to attract even more people concerned about the future of Taiwan to reflect upon the relationship between Christianity and the public welfare of society.

The reason why churches in East Germany also became such breeding grounds for dissidents that pushed for citizen movements also had to do with the suppressive policies of the GDR regime.

For instance, in order to get rid of superstitious beliefs, the GDR authorities designed a special rite of passage into adulthood. Although in theory young people could choose whether they wanted to go through the rite of passage provided by the church or the one by the state, in practice they often found out that the ones who had chosen the one provided by the church would encounter obstructions when applying for university. Although this caused some adolescents to choose to avoid the church's rite of passage, it also caused another group of young people, brave enough to stick to their religious values, to turn into potential dissidents (Goeckel, 1990, p. 35). Among this group, some were the sons and daughters of pastors, others enthusiastic participants in youth activities. Both of these groups rather paid a serious price to participate in the rite of passage provided by the church than to participate in the atheist colored rite of passage organized by the communist party. Because they were used to the restrictions imposed upon them since they were young, they were even more to be willing to pursue justice without further thought and take a position critical of the authorities (Pfaff, 2001, p. 284). The Prague Spring of 1968 caused a group of intellectuals to hide in the only remaining place that was safe from communist control in order to discuss the international situation. And the social ministry of the Protestant church also allowed people who were in need of guidance, such as adolescents, alcoholics, and rehabilitated people, to have a reason to take shelter in the church for longer periods of time (Hadjar, 2003, p. 109).

"How could people who are not afraid to die fear death?" By using the thought police to conduct their terrible regimes, dictatorial regimes had in fact created their own enemies. In the GDR, this led to a situation in which the dissidents that the dictators had expelled to the cover of the churches in the end came to overthrow them. In Taiwan, the church dissidents later also facilitated the first change in political party leadership. 


\section{Conclusion}

In general, religious organizations tend to be conservative. Most church leaders teach their congregations the principle to be submissive to the authority. Yet in some cases under the dictatorship, churches with the sense of justice and the love for the weak ones can also turn out to be the shelters of dissents and provide them communication channels via church documents.

The two hypotheses of this paper are both proved by the cases of the Gikong Presbyterian Church of Taiwan and the East German protestant churches: 1) Under the oppressive policies of dictatorships, protestant churches will naturally turn into a breeding ground for dissidents and will train them to promote citizen movements; and 2) Protestant churches facilitated the development of citizen movements due to the alternative ideology and system of values they provided, setting them apart from the one provided by the dictatorial regimes.

While both The Kuomintang (KMT) of the two Chiangs and the SED of East Germany were Leninist-style parties that strictly controlled each segment of society, both the Gikong Presbyterian Church of Taiwan and the East German churches played important roles in the protection of dissidents.

With a "Declaration and Proposal with Regard to State Matters" "Our appeal" and the "Human Rights Manifesto", Taiwan's Presbyterian Church was not only one of the pioneers voicing out criticism against the Chiang regime, but also provided the guideline for dissents. Similarly, the ideas of the Peace Movement and appeals for peace, ecology protection and righteousness brewing the East German dissents were originally raised by the protestant churches in East Germany.

Both the Gikong Presbyterian Church of Taiwan and the East German provided shelters for dissents who latter contributed to the democratization of Taiwan and East Germany.

\section{References}

Central Reform Committee of the KMT. (1978). Revolutionary documents. Bundle No. 77.

Chen, N. Z. (1991). The societal and political ethics of the Taiwanese Presbyterian Church (Taiwan Jidu Changlaohui de Shehui, Zhengzhi Lunli). Taipei: Yongwang.

Cheng, E. (1982). Walking through the valley of the shadow of death (Xingguo Siyin de Yougu). Tainan: Fengsheng Publishing House.

Dielmeier, U. (2001). Kleine deutsche Geschichte (Little German history). Stuttgart: Reclam GmbH.

Du, Q. X. (2004). The history of the religious beliefs of the family of Thomas Liao. The New Messenger, 80, 26-28.

Friedrich, C. J., \& Brezinski, Z. (1965). Totalitarian dictatorship and autocracy. Cambridge: Harvard University Press.

Goeckel, R. F. (1990). The Lutheran Church and the East German State: Political conflict and change under Ulbricht and Honecker. New York, N.Y.: Cornell University Press.

Goerner, M. G., \& Kubina, M. (1995). Die Phasen der Kirchenpolitik der SED und die sich darauf beziehenden Grundlagenbeschlüsse der Partei- und Staatsführung in der Zeit von 1945/46 bis 1971/72 (The phases of the church policy of the SED and the related fundamental decisions of the party and state leadership in the period from 1945/46 to 1971/72). In Enquete-Kommission, Aufarbeitung von Geschichte und Folgen der SED-Diktatur in Deutschland (Review of the History and Consequences of the Socialist Unity Party's Dictatorship in Germany). Bund VI (VolumnVI). Frankfurt/M/: Nomos Verlagsgesellschaft.

Guan, R. J. (2012). Feng Fei-fei directed by the Garrison Command during the "obscene jokes and song supervision" incident". Retrieved August 17, 2018, from http://mypaper.pchome.com.tw/kuan0416/post/1322783928

Hadjar, A. (2003). Non-violent political protest in East Germany in the 1980s: Protestant Church, opposition groups and the people. German Politics, 12(3), 107-128.

Henke, K. (1995). Anatomie der Staatssicherheit. Geschichte, Struktur, Methoden (MfS-Handbuch). (zus. mit Siegfried Suckut/Clemens Vollnhals/Walter Süß/Roger Engelmann), Berlin. 
Hsu, T. (2012). My days at the Gikong Presbyterian Church. Retrieved August 17, 2018, from http://www.laijohn.com/archives/pc/khou/Khou,Thian/recollect/gi-kong.htm

Kuppe, J. (1999). “Deutschlandpolitik der DDR” in Werner Weidenfeld und Karl-Rudolf Korte Handbuch zur deutschen Einheit 1949-1989-1999. Frankfurt: Campus Verlag.

Lee, S. (1992). The Gikong beated hatred (Yingguo Chouhen de Yiguang). In 10 Year Anniversary Commemoration Booklet of the Taiwanese Gikong Presbyterian Church (Taiwan Jidu Changlaohui Yiguang Jiaohui Shejiao Shizhounian Jiniance). Taipei: Gikong Presbyterian Church. Quoted from Xie Mingdao's MA thesis.

Leonhard, W. (1990). Das kurzen Leben der DDR: Berichte und Kommentare aus vier Jahrzehnten (The Short Live of the GDR: Reports and Commentaries of Four Decades). Sttutgart: Deutsche Verlags-Anstalt.

Li Mei-shu Memorial Gallery. (2004). The people in Li Mei-shu’s paintings appear to be talking. Retrieved August 17, 2018 from http://www.geocities.jp/skytenky/1/h04716h.html

Li, S. J. (1988). Research on the Investigation Bureau (Diaochaju Yanjiu). Taipei: Li Ao Publishing House

Lu, X. L. (2001). Reinvestigating formosa (Chongshen meilidao). Taipei: Qianwei Publishing House.

Lu, Y. L. (2014). Political science (Rev. Sixth ed.). Taipei: Sanmin Book Co.

Luo, J. H. (2012). Blood sacrifices on the road to democracy: Jointly discussing the Lin residence tragedy and Cheng Nan-jung's self-immolation (MA thesis, the Graduate Institute of Taiwanese Culture, National University of Education)

Maser, P (1999). “Kirchen” in Werner Weidenfeld und Karl-Rudolf Korte Handbuch zur deutschen Einheit 1949-1989-1999. Frankfurt: Campus Verlag.

Merkl, P. H. (1993). German unification in the European context. Pennsylvania: the Pennsylvania State University.

Pfaff, S. (2001). The politics of peace in the GDR: The independent peace movement, the church, and the origins of the east German opposition. Peace and Change, 26(3), 280-300.

Shen, W. (2013). Large and small things in Taiwanese history/the Garrison Command carried out an extensive ban on songs. Taiwan Times, 1 June.

The Presbyterian Church in Taiwan. (1999). The Presbyterian Church in Taiwan and the Kaohsiung Incident: Collected works to commemorate its 20th anniversary. Taiwan: The Presbyterian Church in Taiwan.

Thomberry, M. (2011). Fireproof moth: A missionary in Taiwan's white terror (X. R. Lai, Trans.). Taipei: Asian Culture.

Thumfart, A. (2002). Die politische integration ostdeutschlands (The political integration of East German). Frankfurt/M: Suhrkamp Verlag.

United Daily News. (1980). A tragedy occurred in Lin Yi-hsiung's residence: Out of a grandmother and three of her granddaughters three died and one suffers serious injuries. United Daily News, 29 February, 1980.

Wei, C. (2013). Reading Wu Jiemin's The Third Imagination of China. Reflection, 24, 298.

Witt, A. (1996). CDU und LDPD der DDR unter Anpassungsdruck (East Germany's Chrisitan Democratic Party and Liberal Democratic Party under Adjustment Pressure). In W. Dümcke, \& F. Vilmar (Eds.), Kolonialisierung der DDR: Kritische analysen und alternativen des Einigungsprozesses (Colonization of the GDR: Critical Analysis and Alternative of the Process of Unification) (pp. 78-93). Münster: Agenda-Verlag.

Wu Y. F. (1995). History of Germany in the 20th century (Ershishiji Deguo Shi). Taipei: Zhiyi.

Xie, D. L. (2010). Witnessing the favorable footprints of the times: The actual recordings of Misses Kao Li Li-chen (Jianzheng Shidai de Endian Zuji: GaoLiLizhen Nvshi Koushu Shilu). Taipei: Taiwan Theological College.

Xie, M. D. (2013). Researching the Gikong Presbyterian Church: 1982-2012 (MA thesis, Graduate Institute of Taiwanese Culture, National Taipei University of Education).

Xu, J. L. (1996). History of Post-War Taiwan (Zhanhou Taiwan Shiji). Taipei: Bun-eido Publishing Co., Ltd.

Ye, Y. M. (1999). The German problem and the unification of the two Germanies (Deguo Wenti yu Liangde Tongyi). Taipei: National Institute for Compilation and Translation,

Zhu, X. L. (2010). Shallowly discussing religious organizations and societal movements: Using the independence and peace movements led by the protestant church in East Germany as an example (Qianlun Zongiiao Zuzhi yu shehui yundong: Yiqian Dongde Xinjiao Jiaohui Zhudao de Duli he Heping Yundong Weili). In IWR, Global Religious Culture (Shijie zongjiao wenhua) (Vol. 5, pp. 69-74). China: the Institute of World Religions of the Chinese Academy of Social Sciences. 